PAWEE NoWAK

Uniwersytet Pedagogiczny w Krakowie, Polska - Pedagogical University of Krakow, Poland

\title{
Limity ustawowe a zróżnicowanie kosztów kredytu
}

\section{Statutory Limits and Differentiation of Loan Costs}

Streszczenie: W związku z rosnącym zadłużeniem społeczeństwa coraz ważniejsze staje się kształtowanie kompetencji konsumentów w zakresie podejmowania decyzji kredytowych. Interesy konsumentów chroni się w ramach różnych celów szczególnych. Należą do nich m.in. ochrona przed ponoszeniem nadmiernych opłat oraz przed ryzkiem utraty zdolności spłaty kredytu. Interwencje regulatora w postaci limitów na odsetkowe i pozaodsetkowe koszty kredytu służą realizacji pierwszego z wymienionych celów. Studia literatury przedmiotu oraz wnioski z przeprowadzonej analizy ofert na kredyt gotówkowy największych banków w Polsce wskazują na zróżnicowane znaczenie regulacji w zakresie ograniczania kosztów kredytu. Stopy oprocentowania kredytu gotówkowego, stosowane przez znaczną liczbę banków objętych badaniem, okazały się zbliżone do maksymalnego poziomu ustawowego, co może oznaczać, iż regulacje stanowią faktyczną barierę chroniącą konsumentów przed ponoszeniem nadmiernych kosztów. Natomiast w odniesieniu do pozaodsetkowych koszów kredytu wysokość opłat okazała się odległa od limitów ustawowych, co oznacza brak faktycznego znaczenia ograniczeń w tym segmencie rynku kredytowo-pożyczkowego. Ponadto, stopień zróżnicowania całkowitych kosztów kredytu w analizowanych ofertach kredytu gotówkowego okazał się wysoki. Oznacza to, że istniejący stan rynku nie chroni konsumentów przed ryzkiem „przepłacenia” za kredyt i nie zwalnia ich z konieczności analizy ofert.

\begin{abstract}
Competence in making credit decisions is becoming increasingly important in view of the growing social debt. The protection of consumer interests is pursued under various specific purposes. These include protection against incurring excessive fees and risk of losing loan repayment capacity. Regulator interventions in the form of interest and non-interest loan costs limits are used to achieve the first of these objectives. Literature studies and conclusions from the analysis of cash loan offers of the largest banks in Poland indicate the diverse importance of regulations in the area of reducing loan costs. The interest rates on cash loans used by a significant number of banks covered by the survey turned out to be close to the maximum statutory level, which may mean that regulations are a real barrier protecting consumers from incurring excessive costs. On the other hand, in relation to non-interest loan costs, the amount of fees turned out to be far from the statutory limits, which entails there is no real significance of restrictions in this segment of the loan and loan market. In addition, the degree of differentiation in total loan costs in the analysed cash loan offers proved to be high. This means that the current state of the market does not protect consumers against the risk of "overpaying" for credit and does not release them from the need to analyse offers.
\end{abstract}


Słowa kluczowe: konsument; koszty kredytu; kredyt konsumencki; ochrona konsumenta; porównywalność ofert kredytowych; proces kredytowy

Keywords: consumer; consumer credit; consumer protection; credit costs; credit process; comparability of credit offers

Otrzymano: 24 listopada 2019

Received: 24 November 2019

Zaakceptowano: 30 maja 2020

Accepted: 30 May 2020

Sugerowana cytacja/Suggested citation:

Nowak, P. (2020). Limity ustawowe a zróżnicowanie kosztów kredytu. Przedsiębiorczość - Edukacja [Entrepreneurship - Education], 16(2), 239-249. doi: 10.24917/20833296.162.19

\section{Wstęp}

Ochrona konsumentów przed ponoszeniem wygórowanych kosztów spłaty kredytów i nadmiernym zadłużeniem mieści się w centrum działań regulacyjnych. Jest ona ważna ze względu na interes pojedynczych konsumentów oraz na ryzyko systemowe. Pierwszy z celów realizowany jest przez regulatora na rynku kredytowo-pożyczkowym m.in. przez wprowadzanie limitów ustawowych na opłaty pobierane przez banki (ceny maksymalne). Jak wiemy, ingerencja państwa w wolny rynek przez bezpośrednie narzucanie cen (maksymalnych lub minimalnych) prowadzi do zniekształceń w sferze produkcji i konsumpcji (Milewski, Kwiatkowski, 2018: 131-133; Szpringer, 2009: 213-238). Ceny maksymalne wymuszają na przedsiębiorcach redukcję kosztów i eliminują z rynku produkty droższe, często o wyższej jakości, których przy niskim poziomie cen nie opłaca się dostarczać. W efekcie często, mimo szlachetnych intencji regulatora, konsumenci na regulacji nie zyskują, tylko tracą.

Rynek kredytowo-pożyczkowy w Polsce charakteryzuje się wysokim stopniem rozproszenia. Działalność kredytowo-pożyczkową prowadzi wiele podmiotów: banki komercyjne, przedsiębiorstwa pożyczkowe, banki spółdzielcze, spółdzielcze kasy oszczędnościowo-kredytowe oraz osoby prywatne. Dominującą rolę odgrywają banki, w których gospodarstwa domowe mają około 95\% wartości łącznych zobowiązań kredytowo-pożyczkowych (Czapiński, Panek, 2015: 73). Stopień koncentracji sektora bankowego w Polsce na tle innych krajów europejskich jest niski, co oznacza silną konkurencję i bogaty wybór dla konsumentów (Koncentracja...).

Silną pozycję konsumentów - poza rozproszeniem rynku - determinują stosunkowo jednorodny charakter produktów, jakimi są kredyty, oraz struktura informacyjna rynku. Produkty kredytowe na tle innych produktów finansowych charakteryzują się względnie niskim stopniem złożoności. Dodatkowo, dzięki internetowym porównywarkom kredytowym oraz obowiązku ustawowemu podawania informacji o warunkach kredytu w zestandaryzowanej formie, konsumenci mogą łatwiej porównać oferty i podjąć właściwą decyzję. Biorąc pod uwagę powyższe rynkowe i instytucjonalne przesłanki, należałoby się spodziewać niskiego i wyrównanego poziomu cen produktów kredytowych.

Celem niniejszego artykułu jest ocena wpływu ustawowych limitów na koszty kredytu oraz analiza zróżnicowania cen kredytów gotówkowych, oferowanych klientom detalicznym (konsumentom) przez wiodące banki w Polsce. W artykule stara się odpowiedzieć na następujące pytania: 
- Jakie są limity ustawowe na odsetkowe i pozaodsetkowe koszty kredytu?

- Jaki jest „dystans” pomiędzy ustawową, maksymalną wysokością opłat a kosztem wybranych kredytów?

- Czy zróżnicowanie kosztów kredytu gotówkowego na rynku jest wysokie, czy niskie?

- Jakie wskazówki wynikają dla konsumentów z obecnej sytuacji?

- W jakiej relacji pozostaje ochrona konsumentów przed ponoszeniem nadmiernych kosztów z innymi celami szczególnymi regulacji?

Artykuł powstał na podstawie studiów literatury przedmiotu oraz wyników analizy ofert na kredyt gotówkowy dziewięciu największych banków w Polsce. Dane do analizy zostały uzyskane metodą tajemniczego klienta w maju 2017 r., kiedy zwrócono się do banków o przedstawienie oferty na kredyt gotówkowy w kwocie 20 tys. zł na okres dwóch lat.

\section{Odsetkowe koszty kredytu}

Udzielając kredytu, banki pobierają należne sobie wynagrodzenie za udostępnienie kredytobiorcy środków pieniężnych oraz za usługi świadczone w trakcie procesu kredytowego. Wynagrodzenie banku jest kosztem kredytu, który ponosi kredytobiorca. Na koszt kredytu składają się odsetki oraz prowizje i opłaty. Wchodzą one w skład odsetkowych (odsetki) i pozaodsetkowych (prowizje i opłaty) kosztów kredytu.

Odsetki są kosztem związanym z udostępnieniem przez bank kapitału. Kodeks cywilny nie definiuje pojęcia odsetek. Odsetki uznaje się za wynagrodzenie, które należy zapłacić za korzystanie z cudzych pieniędzy, bądź rekompensatę z tytułu opóźnienia w spłacie sumy pieniężnej (Olejniczak, 2014). Roszczenie odsetkowe nie może powstać bez roszczenia o zapłatę zasadniczej sumy pieniężnej. Z tego względu świadczenie odsetkowe ma charakter akcesoryjny (uboczny) (Wiśniewski, 2018a).

Obowiązek zapłaty odsetek wynika najczęściej bezpośrednio z umowy zawartej pomiędzy stronami i odnosi się przede wszystkim do odsetek kapitałowych. Możliwość wprowadzenia do umowy obowiązku zapłaty odsetek wynika ze swobody kontraktowej stron.

Odsetkowe koszty kredytu stanowią część raty kredytu. Rata, którą płaci kredytobiorca, składa się z części kapitałowej i części odsetkowej. Przy kredytach gotówkowych banki wymagają spłaty kredytu w ratach annuitetowych (stałych w całym okresie kredytowania). Przy zastosowaniu takiego sposobu spłaty kredyt jest droższy dla kredytobiorcy niż w przypadku rat malejących (Penczar i in., 2015: 12-29).

Wysokość kosztów odsetkowych wynika z oprocentowania kredytu. Stopę oprocentowania banki określają według formuły WIBOR plus marża banku. Z kolei wysokość marży jest zależna od ponoszonego przez bank ryzyka i w przypadku kredytów na wysokie kwoty bywa przedmiotem negocjacji z kredytobiorcą. Łączna kwota odsetek zależy głównie od wysokości kwoty kredytu, okresu kredytowania i sposobu spłaty zadłużenia, a w małym stopniu - od stopy oprocentowania, i określa całkowity koszt kredytu dla kredytobiorcy.

Stopa oprocentowania może być taka sama dla wszystkich klientów, ale również może zostać określona indywidualnie, po analizie ryzyka danego klienta. W kredytach gotówkowych, banki stosują oprocentowanie jednolite, niezależne od wyniku oceny wiarygodności finansowej klienta (Dobosiewicz, 2001: 114). 
Oprocentowanie kredytu może być stałe lub zmienne. Oprocentowanie stałe chroni kredytobiorców przed ryzykiem wzrostu stóp procentowych w przyszłości. Z jednej strony takie rozwiązanie jest korzystne, ponieważ stabilizuje koszt kredyty, ale z drugiej strony pozbawia ono kredytobiorców korzyści w przypadku spadku stóp procentowych. Obecnie stopy procentowe są najniższe po 1989 r., co oznacza, że należy spodziewać się ich wzrostu w przyszłości. Powinno to skłaniać konsumentów, zainteresowanych długoletnim kredytem, do rozważenia zaciągnięcia kredytu ze stałym oprocentowaniem.

Wysokość odsetek (oprocentowania) i kosztów pozaodsetkowych kształtowana jest przez przepisy prawa i rynek. $Z$ jednej strony ustawodawca nakłada na instytucje finansowe limity wysokości opłat, a z drugiej strony wynikają one z kosztów działalności instytucji finansowych, popytu ze strony kredytobiorców i konkurencji (Dobosiewicz, 2007: 51). Argumentem za normatywnym uregulowaniem maksymalnej wysokości odsetek jest ograniczenie w stosunkach cywilnoprawnych odsetek znacznej wysokości (Wałęga, 2013: 57).

W wyniku nowelizacji Kodeksu cywilnego Ustawa z dnia 9 października 2015 r. o zmianie ustawy o terminach zapłaty $w$ transakcjach handlowych, ustawy - Kodeks cywilny oraz niektórych innych ustaw (Dz.U. 2015 r., poz. 1830) od dnia 1 stycznia 2016 r. odsetki ustawowe są równe sumie stopy referencyjnej NBP i 3,5 p.p. Odsetki maksymalne wynikające z czynności prawnej - odnoszące się również do maksymalnego oprocentowania kredytu - nie mogą w stosunku rocznym przekraczać dwukrotności wysokości odsetek ustawowych (Wiśniewski, 2018b). Według aktualnego stanu prawnego, maksymalna wysokość odsetek nie może przekroczyć $10 \%$ w skali roku. W sytuacji, gdy odsetki wynikające z czynności prawnej przekroczą wysokość odsetek maksymalnych, należą się tylko odsetki maksymalne. Ponadto zastrzeżono, że postanowienia umowne nie mogą ograniczyć lub wyłączyć przepisów o odsetkach maksymalnych.

Zmiany w Kodeksie cywilnym objęły również odsetki za opóźnienie. Wysokość odsetek z tytułu opóźnienia może być określona w umowie lub wynikać $\mathrm{z}$ ustawy. W przypadku, gdy odsetki nie zostały oznaczone w umowie, za każde opóźnienie w spłacie należą się odsetki ustawowe w wysokości równej sumie stopy referencyjnej NBP i 5,5 p.p. Odsetki maksymalne za opóźnienie nie mogą przekraczać dwukrotności wysokości odsetek ustawowych za opóźnienie w stosunku rocznym (tj. 14\% w skali roku).

\section{Pozaodsetkowe koszty kredytu}

Pozaodsetkowe koszty kredytu to wszystkie koszty, które ponosi kredytobiorca-konsument w związku z umową o kredyt konsumencki, z wyłączeniem odsetek (Czech, 2018). Obejmują one zarówno koszty ponoszone jednorazowo, jak i koszty, których wysokość jest uzależniona od okresu kredytowania (Stanisławska, 2018). Do pozaodsetkowych kosztów, wchodzących w skład całkowitego kosztu kredytu, należą prowizja i pozostałe opłaty. Banki pobierają dodatkowe opłaty zarówno przed, jak i po zaciągnięciu kredytu, np. za rozpatrzenie wniosku kredytowego, przygotowanie oferty, przedterminową spłatę kredytu, przewalutowanie kredytu, zmianę wysokości płaconych rat. Opłaty są ustalane kwotowo lub procentowo i mają pełnić funkcję kompensacyjną (Rogoń, 2005; Bączek, 2007).

Prowizja jest głównym pozaodsetkowym kosztem kredytu. Pobierana jest ona za czynności bankowe związane z udzielaniem kredytu. Ma zupełnie inny charakter niż odsetki, które są pobierane za udostępnienie środków finansowych. Celem prowizji jest zrekompensowanie wydatków, które ponosi bank za doprowadzenie do zawarcia 
umowy kredytu, np. kosztów związanych ze sprawdzeniem historii kredytowej klienta w zewnętrznych bazach danych. Prowizja może być pobierana z góry, w formie jednorazowej opłaty, ale również może być skredytowana i rozłożona na raty. Doliczanie opłat pozadosetkowych do kwoty kredytu podnosi całkowity koszt kredytu, ponieważ zwiększa podstawę, od której naliczane są odsetki.

$\mathrm{Z}$ powodu nakładania przez instytucje finansowe dodatkowych, wysokich opłat na kredytobiorców, wprowadzono Ustawa z dnia 5 sierpnia 2015 r. o zmianie ustawy o nadzorze nad rynkiem finansowym oraz niektórych innych ustaw (Dz.U. 2015, poz. 1357), tzw. ustawą antylichwiarską, regulacje dotyczące maksymalnych pozaodsetkowych kosztów kredytu. Celem wprowadzonych limitów była ochrona konsumentów przed zbyt wysokimi prowizjami i dodatkowymi opłatami. Zgodnie z obowiązującą ustawą, maksymalna wysokość pozaodsetkowych kosztów w całym okresie kredytowania nie może przekroczyć całkowitej kwoty kredytu i obliczana jest według następującego wzoru:

$$
M P K K \leq(K \cdot 25 \%)+\left(K \cdot \frac{n}{R} \cdot 30 \%\right)
$$

gdzie:

MPKK - maksymalna wysokość pozaodsetkowych kosztów kredytu,

K - całkowita kwota kredytu,

$\mathrm{n}$ - okres spłaty wyrażony w dniach,

$\mathrm{R}$ - liczba dni w roku.

Podstawą do ustalenia maksymalnej wysokości pozaodsetkowych kosztów kredytu jest całkowita kwota kredytu, która zgodnie z definicją w art. 5 pkt 7 Ustawy z dnia 12 maja 2011 r. o kredycie konsumenckim (Dz.U. $2011 \mathrm{nr}$ 126, poz. $715 \mathrm{ze} \mathrm{zm}$.) oznacza maksymalną sumę środków pieniężnych, które kredytodawca udostępnia kredytobiorcy. Od 11 marca 2016 r. wysokość pozaodsetkowych kosztów kredytu rocznie nie może być wyższa niż suma stanowiąca 25\% całkowitej kwoty kredytu i 30\% kwoty zmiennej, uzależnionej od okresu, na który zaciągnięta została pożyczka (Nowak, 2017). W skali roku kredytodawca może maksymalnie pobrać 55\% wartości kredytu z tytułu opłat pozaodsetkowych. Ponadto, pozaodsetkowe koszty kredytu w całym okresie kredytowania nie mogą przekroczyć 100\% całkowitej kwoty kredytu (Osajda, 2018).

Ustawa nakłada także limit na wysokość kosztów pozaodsetkowych za opóźnienie, które wraz z odsetkami za opóźnienie nie mogą przekroczyć odsetek maksymalnych za opóźnienie, czyli 14\% rocznie.

Przepisy regulujące maksymalną wysokość pozaodsetkowych kosztów kredytu oraz przepisy o odsetkach maksymalnych tworzą system cywilnoprawnej ochrony przed lichwą (Czech, 2018). Przyczyną wprowadzenia powyższych ustawowych regulacji był szeroki i stosunkowo łatwy dostęp do rynku kredytowo-pożyczkowego, bardzo dynamiczny wzrost tego rynku w ostatnim okresie oraz niski poziom wiedzy finansowej kredytobiorców.

Porównanie całkowitych kosztów kredytu, a więc wszystkich kosztów, które musi ponieść kredytobiorca w związku z kredytem, umożliwia rzeczywista roczna stopa oprocentowania (RRSO). Zgodnie z definicją RRSO, zawartą w art. 5 pkt 12 Ustawy z dnia 12 maja 2011 r. o kredycie konsumenckim jest to całkowity koszt kredytu ponoszony przez konsumenta, wyrażony jako wartość procentowa całkowitej kwoty kredytu w stosunku 
rocznym. RRSO ma charakter informacyjny, umożliwia konsumentom porównanie ofert na podstawie tych samych kryteriów, przy użyciu ujednoliconych pojęć (Gafrikova, 2016: 61-75). RRSO wzrasta wraz ze wzrostem stopy oprocentowania kredytu oraz innych składników kosztów (Golec, 2016: 222).

Celem wprowadzenia obowiązku podawania przez kredytodawców rzeczywistej rocznej stopy oprocentowania było ułatwienie konsumentom porównania kosztów kredytu i podjęcie właściwej decyzji (Koleśnik, 2016: 93). Konsument ma prawo do uzyskania w tym zakresie jasnej, przejrzystej i zrozumiałej informacji z uwagi na złożony charakter umów kredytowych (Rutkowska-Tomaszewska, 2011: 97-112). Jednak wskaźnik ten ma poważne mankamenty - nie uwzględnia ryzyka zmiany oprocentowania w czasie trwania umowy kredytu i nie jest adekwatny do określania kosztów kredytów niskokwotowych, na krótki okres. Obowiązek podawania rzeczywistej rocznej stopy oprocentowania spoczywa na kredytodawcy lub pośredniku finansowym, a nieprawidłowe realizowanie tego obowiązku może skutkować sankcją administracyjną.

\section{Zróżnicowanie kosztów kredytu konsumenckiego w świetle wyników badań własnych}

Banki do badania wybrano na podstawie danych o wartości portfela kredytów konsumpcyjnych dla osób fizycznych, opublikowanych przez miesięcznik „Bank”, oraz listy najlepszych banków tygodnika „Newsweek”. Były to banki dominujące na rynku, mające najsilniejszą pozycję na rynku kredytów detalicznych: PKO Bank Polski, Bank Pekao, Getin Bank, Bank BGŻ PNB Paribas, Deutsche Bank, Eurobank, Santander Consumer Bank, mBank i ING Bank Śląski. Badanie przeprowadzono metodą tajemniczego klienta w maju 2017 r., na podstawie ofert na kredyt gotówkowy w kwocie 20 tys. zł na okres dwóch lat.

Całkowity koszt kredytu w przebadanych ofertach obją:

- odsetki,

- prowizję od udzielonego kredytu,

- opłatę przygotowawczą za rozpatrzenie wniosku oraz sporządzenie i zawarcie umowy o kredyt,

- składkę na ubezpieczenie.

Elementami kosztu, które wystąpiły we wszystkich ofertach, były odsetki i prowizja od udzielonego kredytu (tabela 1). Najwyższe oprocentowanie (odsetki) wystąpiło w PKO Bank Polski (9,99\%), a najniższe - w BGŻ BNP Paribas (4,40\%) i Deutsche Bank (4\%). Różnica pomiędzy najwyżej a najniżej oprocentowanym kredytem wyniosła aż 5,99 p.p. Oprocentowanie kredytu w czterech bankach było zbliżone do wysokości obowiązującego limitu ustawowego (10\%). Najwyższe oprocentowanie oferował PKO Bank Polski (9,99\%), a następnie: Getin Bank (8,79\%), ING Bank Śląski (8,74\%) i Bank Pekao (8,50\%). Na tej podstawie można stwierdzić, że obowiązujący limit ustawowy na odsetkowe koszty kredytu ma faktyczne znaczenie i stanowi barierę dla odsetkowych kosztów kredytu.

Również duże okazały się różnice pomiędzy ofertami dotyczące prowizji. Najwyższą prowizję (12,99\%) pobierał PKO Bank Polski, a najniższą - Bank Pekao (3\%). Kwotowa różnica pomiędzy najwyższą a najniższą prowizją wyniosła aż 1979,44 zł. Prowizja - podobnie jak inne opłaty dodatkowe - przewidziana była we wszystkich ofertach i podlegała oprocentowaniu. PKO Bank Polski okazał się najdroższym bankiem - oferował 


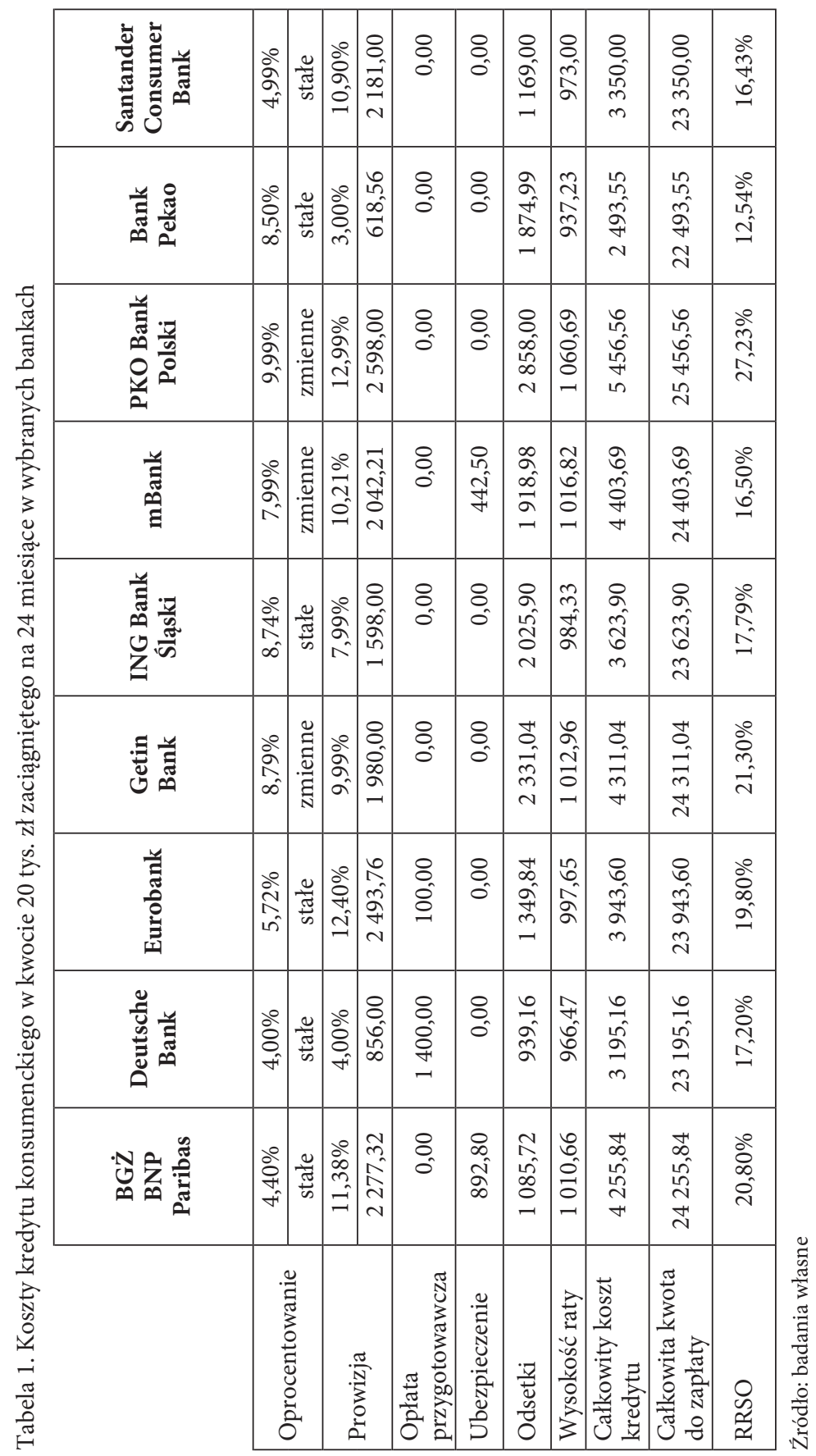


najwyższe oprocentowanie i prowizję. W przypadku BGŻ BNP Paribas wystąpiła odwrotna zależność pomiędzy wysokością oprocentowania a prowizją (bank rekompensował sobie niskie oprocentowanie wysoką prowizją). Natomiast w przypadku Deutsche Bank pojawiła się dodatkowa opłata przygotowawcza, nieobecna w innych ofertach, w wysokości 1400 zł. Po uwzględnieniu wszystkich kosztów kredyt w Deutsche Bank okazał się dużo droższy niż mogłoby na to wskazywać niskie oprocentowanie. Potwierdza to tezę, że niektóre banki obniżają odsetki, a podnoszą opłaty pozadosetkowe (Swat, 2006: 83), manipulują opłatami w celu wyeksponowania niskiego oprocentowania kredytu w działaniach promocyjnych i marketingowych (Bień, A., Bień, W. 2009: 29).

Limit pozaodsetkowych kosztów dla kredytu przyjętego w badaniu wyniósł 85\% kwoty kredytu (17 000 zł). Wysokość pozaodsetkowych kosztów w analizowanych ofertach była zasadniczo poniżej tej kwoty. Oznacza to, że istniejący limit na pozaodsetowe koszty kredytu nie ma faktycznego znaczenia dla kredytów tego typu - na wyższe kwoty i dłuższy okres kredytowania. Powyższy limit ma zastosowanie przy pożyczkach oferowanych na niskie kwoty i krótki okres spłaty.

Najważniejszym wyznacznikiem kosztu kredytu jest całkowity koszt kredytu, stanowiący różnice pomiędzy całkowitą kwotą do zapłaty przez kredytobiorcę a wypłaconą kwotą kredytu przez kredytodawcę. Rozpiętość całkowitego kosztu kredytu w badanej próbie okazała się bardzo duża. Różnica pomiędzy najdroższym kredytem oferowanym przez PKO Bank Polski (5456,56 zł) a najtańszym kredytem oferowanym przez Bank Pekao (2493,55 zł) wyniosła aż 2963,01 zł. Wielkości tej różnicy nie widać przy porównaniu wysokości raty - w PKO Bank Polski było to 1060,69 zł, a w Banku Pekao 937,23 zł. Jednak to 123,46 zł różnicy miesięcznie daje w sumie tak dużą kwotę. Różnica w wysokości 2963,01 zł jest bliska kwocie całkowitego kosztu kredytu w ofertach kilku banków.

Najdroższa oferta dotyczyła kredytu z ubezpieczeniem. Część banków oferowała kredyt tylko z ubezpieczeniem. Ubezpieczenie dołączane do kredytu znalazło się w ofertach dwóch banków: BGŻ BNP Paribas oraz mBank. Ubezpieczenie mocno różnicuje oferty oraz obniża, a nawet uniemożliwia ich porównanie. W ofercie z ubezpieczeniem klient dostaje więcej korzyści niż w ofercie bez ubezpieczenia i to on musi zdecydować, czy warto zapłacić więcej. Kredytobiorca, stając przed wyborem kredytu z ubezpieczeniem, powinien pamiętać, że istnieją również inne środki zabezpieczenia przed ryzykiem kredytowym, takie jak: majątek, oszczędności, rezerwy czy pożyczka od rodziny. Mając na uwadze powstałe ryzyko, powinien wybrać rozwiązanie najlepiej dopasowane do swoich potrzeb i najtańsze.

Porównywalność ofert jest istotnie ograniczona również przez rodzaj oprocentowania. W przypadku kredytów z oprocentowaniem zmiennym istnieje ryzyko zmiany stóp procentowych, natomiast $\mathrm{w}$ przypadku kredytów z oprocentowaniem stałym nie ma takiego ryzyka. W przebadanej grupie większość kredytów oferowana była z oprocentowaniem stałym. Tym samym, w większości przypadków, kredytobiorcy nie byli narażeni na ryzyko zmiany stóp procentowych. W umowach kredytu o zmiennym oprocentowaniu bank zobowiązany jest określić w umowie kredytu w jasny, obiektywny i weryfikowalny sposób zasady zmiany oprocentowania (Ofiarski, 2011). Postanowienia umowne niespełniające tych wymagań są niezgodne z prawem i nie wiążą stron.

Zróżnicowanie ofert pod względem całkowitego kosztu kredytu okazało się wysokie. Wydaje się, że przyczyna tego stanu rzeczy leży po stronie konsumentów, którzy 
koncentrują się na tym, czy kredyt dostaną, i jaka jest wysokość raty, a nie interesują się całkowitym kosztem kredytu. Ponadto nie sprawdzają i nie porównują ofert w celu wybrania najkorzystniejszej.

Z przeprowadzonego badania wynika ponadto, że najtańszym bankiem nie był bank główny, w którym klient ma rachunek oszczędnościowo-rozliczeniowy. Cena kredytu w banku głównym (Deutsche Bank) wyniosła 3195,16 zł i była o 701,61 zł wyższa niż w banku najtańszym. Mogłoby się wydawać, że bank główny, w którym na rachunek klienta wpływa miesięczne wynagrodzenie i który wie o nim najwięcej, powinien zaoferować najtańszą ofertę. Tak się jednak nie stało, co oznacza, że cena kredytu wynika z polityki danego banku, a nie $\mathrm{z}$ wiarygodności finansowej i historii klienta. Banki mają różny apetyt na ryzyko, co wpływa na prowadzoną politykę kredytową (Dobosiewicz, 2011: 211). Oznacza to, że konsument nie powinien ograniczać się do swojego banku i powinien sprawdzać ceny u konkurencji. Ma to znaczenie, zwłaszcza przy kredytach mieszkaniowych na duże kwoty, gdzie finansowe konsekwencje złych decyzji są poważne.

Rzeczywisty koszt kredytu znany jest dopiero po zamknięciu kredytu. W fazie przedkontraktowej, na etapie wyboru kredytu, z dostępnych informacji kredytobiorca nie wynika dokładnie, ile naprawdę kredyt go będzie kosztował - może tylko ten koszt szacować. Wybór kredytu spośród dostępnych ofert, na podstawie kosztu kredytu, nie jest w pełni możliwy. Duże różnice w kosztach kredytu pomiędzy bankami mogą pojawić się w fazie pokontraktowej, np. w przypadku opóźnień w spłacie kredytu. Na etapie przedkontraktowym kredytobiorca nie jest w stanie ocenić ofert pod tym względem.

Z badania wynika, że szukając najtańszego kredytu, warto pytać o oferty promocyjne banku. Banki mają często swoje „hity” kredytowe, oferowane na szczególnie korzystnych warunkach. Kredyty promocyjne cechuje narzucona przez bank górna kwota i maksymalny okres spłaty. Klient musi liczyć się z tym, że może nie zmieścić się ze swoimi planami w tych ramach. W takiej sytuacji będzie musiał swoje wcześniejsze plany skorygować tak, aby dopasować je do dostępnej oferty. Niemniej jednak klienci powinni pytać o promocyjne oferty dlatego, że ich warunki mocno odbiegają in plus od warunków standardowych.

\section{Zakończenie}

Wpływ limitów ustawowych na odsetki i opłaty dodatkowe pobierane przez kredytodawców ma zróżnicowany charakter. W przebadanej próbie oprocentowanie kredytów gotówkowych było zbliżone do ustawowej granicy, co może świadczyć o pozytywnym znaczeniu regulacji antylichwiarskich, natomiast wysokość opłat pozaodsetkowych była od tej granicy daleka. Tak więc w przypadku opłat dodatkowych ograniczenia ustawowe mogą mieć znaczenie dla innych kredytów - mogą wpływać na niższe kwoty i krótszy okres spłaty. W ofertach zauważalna była odwrotna zależność pomiędzy wysokością oprocentowania a opłatami dodatkowymi - kredyty niżej oprocentowane miały wyższe prowizje i odwrotnie. Wymagało to od konsumenta umiejętności kompleksowego spojrzenia na czynniki kształtujące całkowite koszty kredytu, a nie kierowania się tylko wysokością oprocentowania. 
Skuteczność państwa w zakresie ochrony kredytobiorców przed nadmiernymi kosztami kredytu przez limitowanie opłat jest co najmniej wątpliwa. Po wprowadzeniu limitów na pozaodsetkowe koszty kredytu zanotowano wzrost średniej kwoty udzielanego kredytu i wydłużenie okresu kredytowania. Z całą pewnością kredyty na małe kwoty stały się dla kredytodawców nieopłacalne i powstał w ten sposób nacisk na zwiększanie kwot kredytu. Limity wywołały u kredytodawców cięcia kosztów działalności i rozwój sprzedaży zautomatyzowanej, z ograniczeniem czasu poświęcanego klientom.

Przepisy ograniczające wysokość opłat mają zastosowanie do każdego kredytodawcy z osobna. W przypadku korzystania z usług pośredników kredytowych, mających w ofercie produkty finansowe wielu instytucji finansowych lub zwracania się o kredyt przez konsumentów do różnych kredytodawców, są one zupełnie nieskuteczne. Oznacza to, że nie limity opłat, ale rzetelna ocena zdolności kredytowej może chronić przed nadmiernym zadłużeniem i związanym z tym wysokim kosztem i ryzkiem kredytowym.

Koszt kredytu powinien być przedmiotem uwagi i zainteresowania kredytobiorców ze względu na duże ryzyko poniesienia nieuzasadnionych rynkowo kosztów. Zróżnicowanie kosztów kredytu w przebadanej próbie okazało się wysokie - kredyt najdroższy był ponad dwukrotnie droższy od kredytu najtańszego - mimo iż względnie wysoka jednorodność produktów kredytowych, wysokie rozproszenie rynku kredytowego oraz ułatwienia $\mathrm{w}$ dostępie do informacji mogą sugerować wyrównany poziom cen. Wydaje się, że przyczyn takiego stanu rzeczy należy szukać po stronie kredytobiorców. Ceny są zróżnicowane, ponieważ pozwalają na to klienci. Chociaż kredytobiorcy mają możliwość kontrolowania cen, to tego nie czynią i przepłacają. Konsumenci poszukujący kredytu powinni być aktywni i nie powinni ograniczać się do banku, który prowadzi ich rachunek oszczędnościowo-rozliczeniowy, ponieważ nie gwarantuje to uzyskania najlepszej oferty.

Porównywanie ofert ograniczają natomiast niejednolite oprocentowanie (stałe lub zmienne), dodatkowe produkty oferowane łącznie z kredytem (np. ubezpieczenie) oraz niepewność związana z rzeczywistymi kosztami kredytu w przypadku wystąpienia problemów z terminową spłatą kredytu, znanych dopiero po zamknięciu kredytu.

Literatura

References

Bączyk, M. (2007). Komentarz do art. 110 ustawy Prawo bankowe. W: E. Fojcik-Mastalska (red.), Prawo bankowe. Komentarz. LexisNexis/el.

Bień, A., Bień, W. (2009). Kalkulacja ceny pieniądza w lokatach, pożyczkach i kredytach. Warszawa: Difin.

Czapiński, J., Panek, T. (red.). (2015). Diagnoza społeczna 2015. Warunki i jakość życia Polaków. Warszawa: Rada Monitoringu Społecznego.

Czech, T. (2018). Komentarz do art. 36a ustawy o kredycie konsumenckim. W: T. Czech, Kredyt konsumencki. Komentarz. Wolters Kluwer Polska/el.

Dobosiewicz, Z. (2011). Bankowość. Warszawa: PWE.

Dobosiewicz, Z. (2007). Kredyty i gwarancje bankowe. Warszawa: PWE.

Dobosiewicz, Z. (2001). Podstawy bankowości. Warszawa: Wydawnictwo Naukowe PWN.

Gafrikova, V. (2016). Koszty kredytu konsumenckiego w świetle regulacji prawnych. Przedsiębiorstwo Przyszłości, 4(29), 60-75.

Golec, M.M. (2016). Instytucje i ustugi bankowe. Poznań: Wyższa Szkoła Bankowa.

Koleśnik, J. (2016). Bankowość detaliczna. Warszawa: Difin. 
Koncentracja sektora bankowego. (2019, 15 listopada). Pozyskano z: https://www.knf.gov.pl/Images/ KONCENTRACJA_SEKTORA_BANKOWEGO-prezentacja_tcm75-42097.pdf

Milewski, R., Kwiatkowski, E. (2018). Podstawy ekonomii. Warszawa: PWN.

Nowak, P. (2017). Bezpieczeństwo konsumenta w transakcjach kredytowych. Przedsiębiorczość Edukacja [Entrepreneurship - Education], 13, 275-288.

Ofiarski, Z. (2011). Prawo bankowe. Warszawa: Wolters Kluwer.

Olejniczak, A. (2014). Komentarz do art. 359 Kodeksu cywilnego. W: A. Kidyba (red.), Kodeks cywilny. Komentarz LEX. Tom III: Zobowiązania - część ogólna. Wolters Kluwer/el.

Osajda, K. (2018). Art. 36a. Ustawa o kredycie konsumenckim. W: K. Osajda (red.), Ustawa o kredycie konsumenckim. Komentarz. C.H. BECK/el.

Penczar, M., Barembruch, A., Górski, P., Liszewska, M. (oprac.). (2015). Odpowiedzialne korzystanie ludzi młodych z usług kredytowych. Gdańsk: Narodowy Bank Polski, Instytut Badań nad Gospodarką Rynkową.

Rogoń, D. (2005). Komentarz do art.110 ustawy - Prawo bankowe. W: F. Zoll (red.), Prawo bankowe. Komentarz. Tom I i II. Zakamycze/el.

Rutkowska-Tomaszewska, E. (2011). Nadzór nad rynkiem finansowym a nieuczciwe praktyki rynkowe banków wobec konsumentów - zakres, potrzeba i możliwości podejmowanych działań. Studia Finansoprawne, 1, 97-112.

Stanisławska, M. (2018). Art. 36a - Ustawa o kredycie konsumenckim. W: M. Stanisławska (red.), Ustawa o kredycie konsumenckim. Komentarz. C.H. BECK/el.

Swat, B. (2006). Kredyt konsumencki. W: D. Korenik (red.), Innowacyjne ustugi banku. Warszawa: Wydawnictwo Naukowe PWN, 71-88.

Szpringer, W. (2009). Społeczna odpowiedzialność banków. Między ochroną konsumenta a osłona socjalną. Warszawa: Wolters Kluwer.

Wałęga, G. (2013). Kredytowanie gospodarstw domowych. Warszawa: PWE.

Wiśniewski, T. (2018a). Komentarz do art. 481 Kodeksu cywilnego. W: J. Gudowski (red.), Kodeks cywilny. Komentarz. Tom III: Zobowiązania - część ogólna. Wolters Kluwer/el.

Wiśniewski, T. (2018b). Komentarz do art. 359 Kodeksu cywilnego. W: J. Gudowski (red.), Kodeks cywilny. Komentarz. Tom III: Zobowiązania - część ogólna. Wolters Kluwer/el.

Paweł Nowak, dr, ekonomista, adiunkt w Katedrze Ekonomii i Polityki Gospodarczej na Wydziale Politologii Uniwersytetu Pedagogicznego im. Komisji Edukacji Narodowej w Krakowie. Jego główne zainteresowania naukowe to: mikro- i makroekonomia, bezpieczeństwo obrotu gospodarczego i ochrona konsumenta. Jest autorem publikacji naukowych z zakresu ekonomii, prawa i finansów.

Paweł Nowak, PhD, economist and assistant professor in the Department of Economics and Economic Policy at the Faculty of Political Sciences of the Pedagogical University of Krakow. His main research interests are: economy, security of transaction and consumer protection. Author of numerous articles on economics, law and finance.

ORCID: https://orcid.org/0000-0002-8160-242X

\section{Adres/Address:}

Uniwersytet Pedagogiczny im. Komisji Edukacji Narodowej

Wydział Politologii

Katedra Ekonomii i Polityki Gospodarczej

ul. Podchorążych 2

30-084 Kraków, Poland

e-mail: pawel.nowak@up.krakow.pl 